\title{
ВЗАИМОЗАВИСИМОСТЬ ТИПОМОРФНЫХ ОСОБЕННОСТЕЙ АЛМАЗОВ С ОПРЕДЕЛЕННЫМИ СОСТАВАМИ МИНЕРАЛОВ ИЗ КИМБЕРЛИТОВ
}

\author{
А. С. Иванов, Б. С. Помазанский \\ НИГП АК «АЛРОСА» (ПАО), РС (Я), г. Мирный \\ Поступила в редакцию 26 июня 2018 г.
}

\begin{abstract}
Аннотация: представлены результаты статистического анализа составов индикаторных минералов кимберлитов (ИМК) и частот встречаемости габитусных форм, ивета фотолюминесиениии алмазов. Комплексный подход к изучению составов ИМК в кластерных областях их составов и свойств алмазов из кимберлитов включает использование кластерного ( $R$ и $Q$ методы) и факторного методов анализа данных. В работе для каждой исследуемой кимберлитовой трубки вычислены характеристические кластерные области составов ИМК, для которых определилась значимая корреляиия с определенными свойствами алмазов. Из результатов анализа вытекают прикладные значения полученных оценок, заключающиеся в использовании в качестве поискового признака кимберлитовых месторождений алмазов факта обнаружения определенных кластерных групп составов ИМК, которые являются поисковыми характеристическими критериями для каждого изученного кимберлитового тела. Высокие и значимые коэффициенты корреляции между частотами встречаемости средних значений составов кластерных групп ИМК, а также определенных форм кристаллов и ивета фотолюминесиенции алмазов, продуктивностью объектов на ИМК и алмазы наблюдаются только в совокупностях трубок, которые локализованы в пределах конкретного кимберлитового поля. Установлено, что на физические свойства решетки кристаллов алмазов оказывает важное действие и геохимическая обстановка, существовавшая на всем протяжении его роста. Присутствие минералов титана и железа, в процессе роста кристалла алмаза склонны приводить к смещению форм кристаллов в сторону ОРД и реже ЛРД форм в сочетании с повышенным содержанием кристаллов с зеленой и желто-зеленой фотолюминесиенцией.
\end{abstract}

Ключевые слова: минералы индикаторы кимберлитов, свойства алмазов, кластерный и факторный анализ.

\section{INTERDEPENDENCE TIPOMORFNYKH OF FEATURES OF DIAMONDS WITH CERTAIN STRUCTURES OF MINERALS FROM KIMBERLITES}

\begin{abstract}
: in this work results of a statistical analysis of compositions of indicator minerals of kimberlites (IMK) and frequencies of occurrence of gabitus forms, colors of a photoluminescence of diamonds are presented. A comprehensive approach to studying of structures of IMK in cluster areas of their structures and properties of diamonds from kimberlites includes use cluster ( $R$ and $Q$ methods) and the factor analysis of data of methods. In work for each studied kimberlite tube their characteristic cluster areas of structures of IMK for which the significant correlation decided on particular physical properties of diamonds are calculated. All calculations are executed from random and representative samples of compositions of grains of minerals from kimberlites of tubes. From results of the analysis applied values of the received estimates, IMK consisting in use as search sign of kimberlite diamond fields of the fact of detection of certain cluster groups of structures which are their search characteristic criteria for each studied kimberlite body follow. It is revealed that high and significant coefficients of correlation between frequencies of occurrence of mean values of structures of the IMK cluster groups and also definite forms of a habitus of crystals and color of a photoluminescence of diamonds, efficiency of objects on IMK and diamonds are observed only in sets of tubes which are localized within the concrete kimberlite field. In work it is established that the geochemical situation, existing throughout its growth, has important effect on physical properties of a lattice of crystals of diamonds also. It is established that presence of minerals of a titanium and iron, in the course of body height of a crystal of diamond to lead slopes to the shift of
\end{abstract}


forms of crystals towards ORD less often than LRD of forms in a combination to the increased maintenance of crystals to a green and flavovirent photoluminescence.

Keywords: minerals indicators of kimberlites, properties of diamonds, cluster and component analysis.

\section{Введение}

Якутская кимберлитовая провинция занимает северо-восточную часть Сибирской платформы. Она протянулась с юга на север на полторы тысячи километров от Малоботуобинского района почти до моря Лаптевых и с запада на восток на тысячу километров от Харамайского поля в Красноярском крае до реки Лена. На севере и востоке границами провинции служат Лено-Анабарский и Ангаро-Вилюйский прогибы, а на юго-востоке - Вилюйская синеклиза и АнгароВилюйский прогиб. На западе границу с меньшей определенностью проводят по восточному склону Тунгусской синеклизы. Ограниченная таким образом Якутская кимберлитовая провинция точно совпадает с областью Анабарского гравитационного максимума, что согласуется с преобладанием здесь структур поднятий. Из крупных платформенных структур, охватываемых провинцией, следует назвать Анабарский щит на северо-западе и Оленекское поднятие на северовостоке вместе с разделяющей их Суханской впадиной и Ботуобинской седловиной. В пределах Якутской кимберлитовой провинции на площади свыше 800 тыс км ${ }^{2}$ расположены многие сотни кимберлитовых трубок. Распределяясь крайне неравномерно, они группируются в 20 кимберлитовых полей, которые обычно объединяют в 8 более или менее обособленных районов.

Пироп, хромистая шпинель, пикроильменит, алмаз относятся к числу ведущих типоморфных минералов большинства мантийных парагенезисов в кимберлитах [1]. Кроме того, эти минералы, несомненно, наиболее информативны и наиболее изучены как представители минералов мантийного происхождения. Их составы и свойства широко используются для решения специальных петрологических задач, а также при поисковых работах на алмазы. Вопрос существования связей между содержанием алмазов и ИМК, свойствами алмазов и составом минераловиндикаторов постоянно интересует исследователей, что нашло отражение в ряде печатных работ [1-5].

Мирнинское, Алакит-Мархинское и Далдынское кимберлитовые поля Якутии являются одними из самых изученных алмазоносных полей. В их пределах сосредоточено более 200 трубочных и жильных тел, группирующихся в отдельные кусты трубок. Для выбранных кимберлитовых трубок в ходе геологических и производственных работ получены концентраты и на примере представительных коллекций изучены минералогия, состав, МСА, морфологические и физические свойства алмазов. Наличие таких материалов из коренных тел этих полей позволило поставить вопрос исследования взаимных связей, сосуществующих парастерических (или парагенетических?) ассоциаций ИМК и алмазов.

\section{Методика исследований}

В данной работе использован метод кластерного и факторного анализа кластерных средних значений составов МСА, который был опубликован авторами ранее [2]. Дополнением к опубликованной методике являются данные по продуктивности ИМК и алмазов, частотам встречаемости габитусных форм кристаллов и цветов фотолюминесценции алмазов.

С помощью кластерного (k-среднего) анализа составы пиропов выборок проб (более 10000 зерен) разбиты на 24 кластерные группы (рис. 1). В номинальном порядке кластерные группы отсортированы по возрастанию окиси хрома (G1-G24). Составы пикроильменитов (более 10000 зёрен, рис. 2) - на 16 кластерных групп, по средне кластерному значению отсортированы по возрастанию окиси магния (P1Р16). Определена частота появления зерен групп ИМК, а также основных габитусных форм кристаллов и цвета фотолюминесценции алмаза, где ОКТ - октаэдр, ЛРД - ламинарный ромбододекаэдр, ОРД - додекаэдроид, ПФ - переходная между октаэдром и ламинарным ромбододекаэдром форма кристалла алмаза. Все характеристики представлены в относительных процентах от объема (более 150 зерен) представительных выборок. Продуктивность на алмазы выражена в условных единицах на тонну породы, продуктивность пиропов и пикроильменитов в относительных процентах на тонну породы.

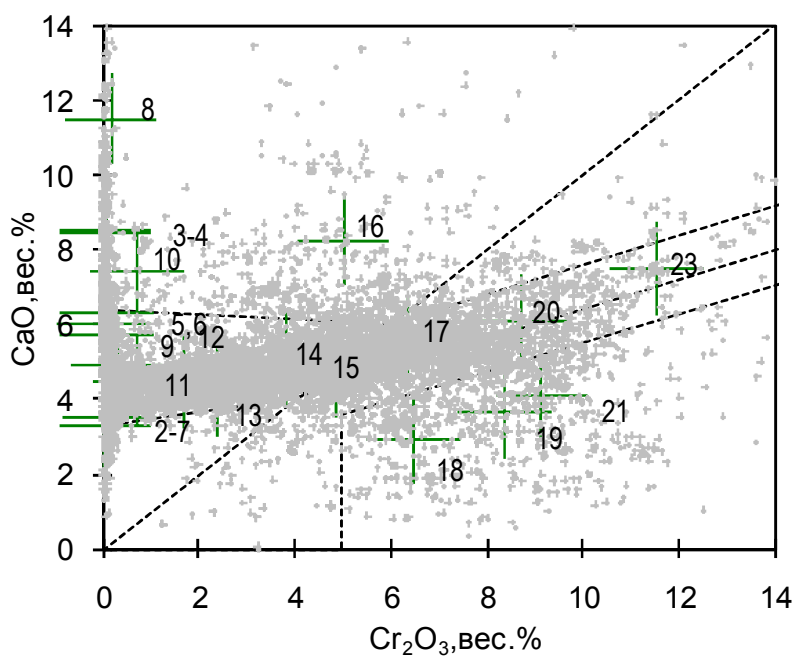

Puc. 1. Состав пиропов Мирнинского, Далдынского и Алакит-Мархинского кимберлитовых полей (серые значки) и средние значения полученных кластерных групп G1-G24 (увеличенные зелёного цвета значки).

Большая часть определений составов ИМК выполнены методом рентгено-спектрального микроанализа (РСМА) в лаборатории НИГП АК «АЛРОСА» (ПАО) на рентгеновском микроанализаторе JXA-8800R 

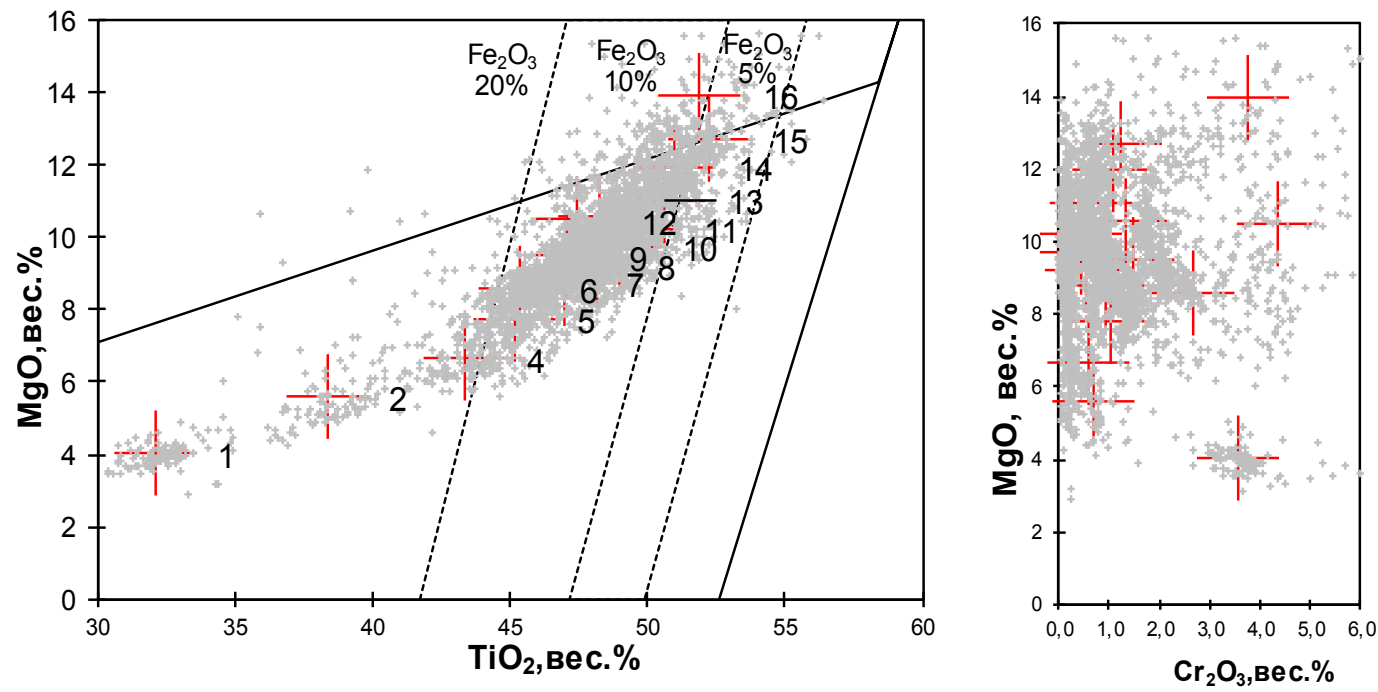

Puc. 2. Состав пикроильменитов Мирнинского, Далдынского и Алакит-Мархинского кимберлитовых полей (серого цвета значки) и средние значения кластерных групп Р1-Р16 -(красного цвета увеличенного размера значки).

(фирма Jeol, Япония). Данные о интересующих нас минералогических свойствах алмазов из кимберлитовых трубок получены в результате обработки массивов результатов исследований лаборатории алмазов НИГП АК «АЛРОСА» (ПАО).

\section{РЕЗУЛЬТАТЫ ИССЛЕДОВАНИЯ}

\section{Мирнинское кимберлитовое поле}

Статистический анализ частот встречаемости составов гранатов, пикроильменитов и характеристик алмазов позволил определить близость этих характеристик для кимберлитовых тел Интернациональное и им. XXIII съезда КПСС (рис. 3). Эти два кимберлитовых тела характеризуются примерно близкими содержаниями в пробах кластерных групп пиропов эклогитовых парагенезисов G7 и G10 и всех групп составов хромистых ультраосновных парагенезисов
G20-G23, включая группы из основных алмазоносных парагенезисов. Характерной особенностью алмазов из этих тел является относительно одинаковое содержание кристаллов в форме октаэдров, а также преобладание розово-сиреневой фотолюминесценции, повышенное содержание в выборках алмазов с зональными и неопределёнными цветами свечения кристаллов [3].

Для кимберлитов типа тр. Мир, на фоне типичного для Малоботуобинского района преобладания алмазов с розово-сиреневой фотолюминесценцией, отмечается повышенное количество кристаллов с фиолетовой фотолюминесценцией, относительное преобладание пикроильменитов кластерной группы Р4 - ферримагнитных зерен. В целом кимберлиты типа тр. Мир более продуктивны на пиропы, чем в остальных телах. В них преобладают кластерные группы пиропов ряда эклогитовых парагенезисов - G5, G6 и G8 с пониженным

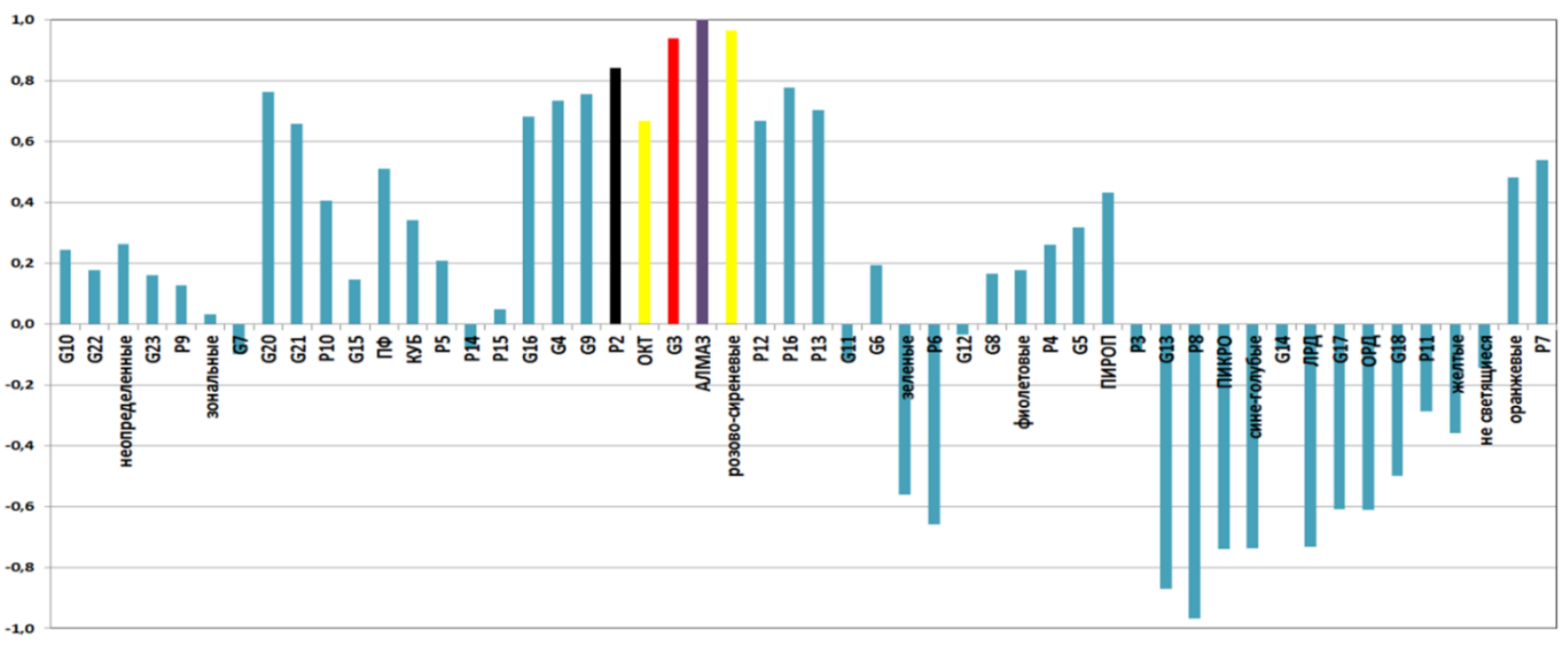

Puc. 3. Гистограммы парных групповых коэффициентов корреляции частот встречаемости кластерных групп ИМК, продуктивности тел (АЛМАЗ), цветов фотолюминесценции алмазов и их кристалломорфологических форм сгруппированные групповым кластерным анализом для Мирнинского кимберлитового поля. 


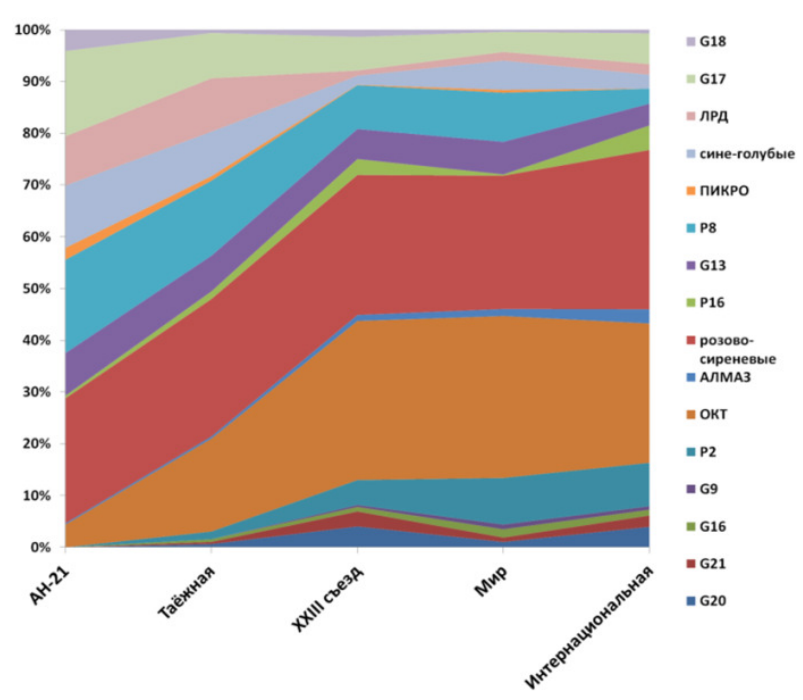

Pис. 4. Характер изменения значимых частот встречаемости кластерных групп ИМК (цифры -относительные от выборки проценты), продуктивности тел (АЛМАЗ), цветов фотолюминесценции алмазов и их кристалломорфологиче- ских форм от слабо алмазоносных к алмазоносным кимберлитам для Мирнинского кимберлитового поля.

значением окиси натрия из эклогитовых сростков с алмазами и групп G12 и G11 из области мегакристов с повышенными значениями окиси титана (рис. 4).

Для малопродуктивных объектов типа жила Ан21 , тр. Таежная, а также не учтенного в данном анализе тр. Амакинская, характерен заметно иной, чем для высокопродуктивных тел, спектр кристалломорфологических форм алмаза. В этих кимберлитах отмечено преобладание ЛРД и ОРД, кристаллов с синеголубыми, белесыми и зеленными и жёлтыми, и жёлто-зелёными цветами фотолюминесценции (рис. 5). Из кластерных групп ИМК отмечено преобладание кластерных составов пикроильменитов Р8 и P11 парамагнитной не высоко хромистых групп, а также кластерных групп пиропов G13 - высоко-титанистых парагенезисов, G14, G17 ультраосновных и G18 алмазоносных слабо хромистых дунит-гарцбургитовых парагенезисов.

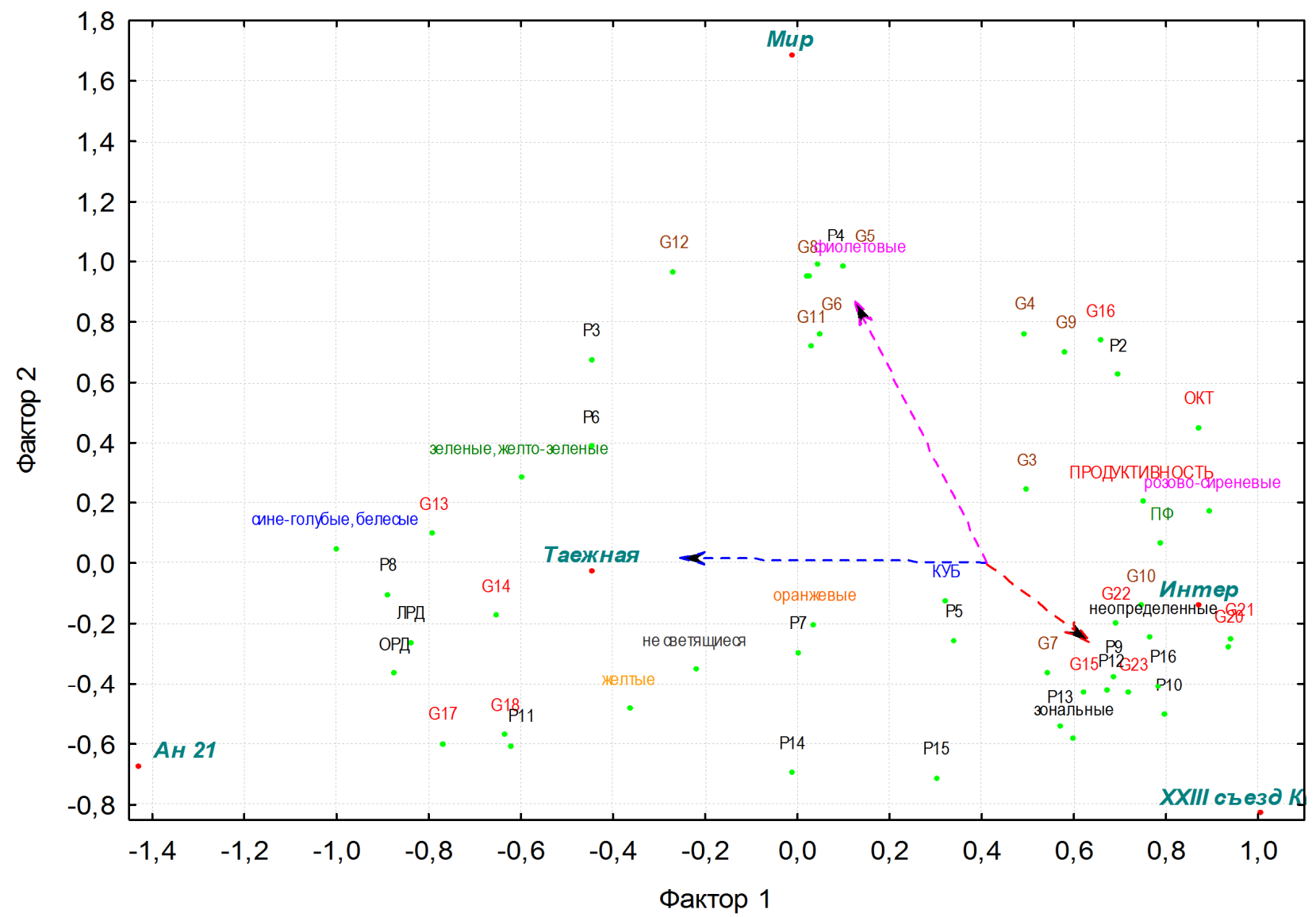

Puc. 5. Диаграмма главных факторов частот встречаемости кластерных групп ИМК, продуктивности тел (ПРОДУКТИВНОСТЬ), цветов фотолюминесценции и кристалломорфологических форм алмазов для кимберлитовых трубок Мирнинского кимберлитового поля.

\section{Далдынское кимберлитовое поле}

В целом для алмазов из высокоалмазоносных трубок Далдынского кимберлитового поля отмечены сопоставимые характеристики. В этих кимберлитах от- мечена относительно повышенная частота встречаемости ОКТ и ЛРД при меньшей доле ПФ и пониженное, относительно основной части малопродуктивных коренных алмазопроявлений поля, содержа- 
ние ОРД. По цвету фотолюминесценции высокие частоты встречаемости алмазов с сине-голубым, желто-зеленым свечением, при относительно пониженном значении кристаллов с розово-сиреневым свечением.

Трубка Удачная на фоне вышеуказанных для высокопродуктивных тел параметров алмазов, отмечено повышенное содержание кристаллов с оранжевой фотолюминесценцией и наблюдается преобладание группы пиропов верлитовых парагенезисов G16 и алмазоносных высокохромистых парагенезисов группы G21. C группой пиропов верлитовых парагенезисов G16 значимо и прямо связана частота встречаемости групп пикроильменитов Р6 (коэффициент корреляции более $+0,9$, рис. $6-8$ ) и в меньшей степени группа P7 и Р9 с не высокими гейкелитовыми миналами. Группа пикроильменитов Р6 характерна для кимберлитов Западного и Восточного тел трубки Удачная. Эта группа пикроильменитов наиболее железистая и с большим гематитовым миналом.

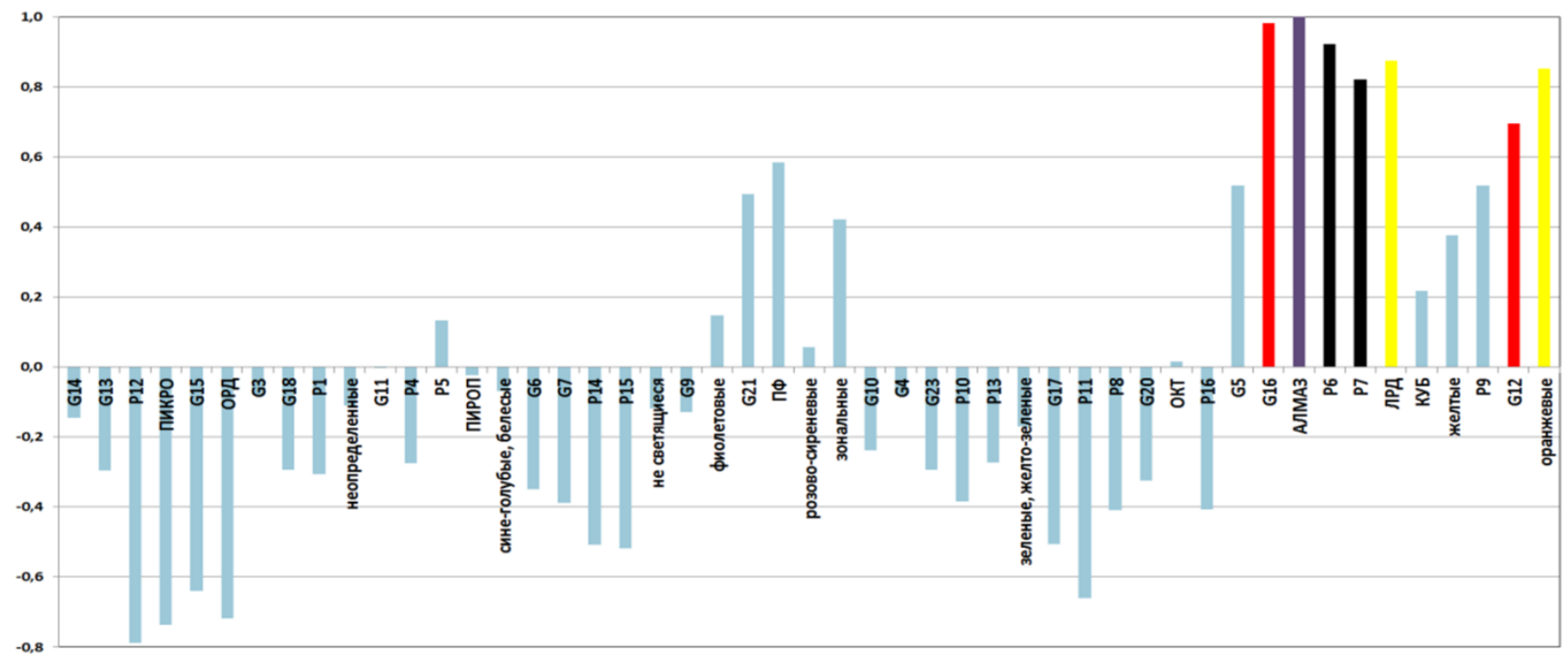

Рис. 6. Гистограммы парных групповых коэффициентов корреляции, частот встречаемости кластерных групп ИМК, продуктивности тел (АЛМАЗ), цветов фотолюминесценции алмазов и их кристалломорфологических форм сгруппированные групповым кластерным анализом для Далдынского кимберлитового поля.

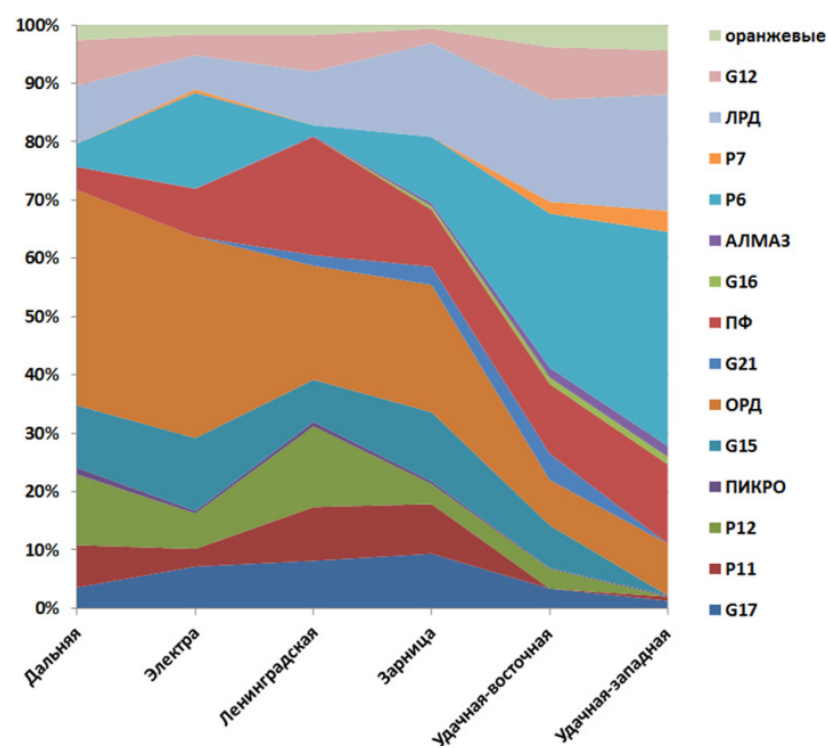

Рис. 7. Характер изменения значимых частот встречаемости (цифры - относительные от выборки проценты) кластерных групп ИМК, продуктивности тел (АЛМАЗ), цветов фотолюминесценции алмазов и их кристалломорфологических форм от слабо алмазоносных к алмазоносным кимберлитам для Далдынского кимберлитового поля.

Среди алмазов тр. Зарница преобладают ОРД, при характерной для поля наиболее высокой частоте встречаемости алмазов с сине-голубым свечением, но относительно повышенном содержании индивидов неопределённого цвета фотолюминесценции. В целом отмечена самая высокая продуктивность по зернам пиропов. Из эклогитовых парагенезисов в пробах преобладают зерна кластерных групп составов G3, G4 и G11. Из ультраосновных парагенезисов преобладают группы составов G13, G15 и G18.

Для кимберлитов тр. Долгожданная отмечена высокая продуктивность на пикроильменит. Относительно повышено содержание кристаллов алмазов кубического габитуса с зеленой и желто-зеленой фотолюминесценцией. Из пикроильменитов преобладают зерна как с высоким эсколаитовым миналом Р10, так и с высоким корундовым миналом Р11 и Р12. Для этих групп составов также определяется гематитовый минал более 20 \%. Из ультраосновных парагенезисов отмечено повышенное содержание зёрен группы G17 и G20, а из эклогитовых парагенезисов преобладают зерна группы G10.

Для кимберлитов типа тр. Ленинградская преобладают кристаллы ПФ и ОКТ с розовой, фиолетовой, желтой, неоднородной зональной фотолюминесценцией, а также не светящиеся. Преобладают группы составов пиропов эклогитовых парагенезисов G3, G6 и G9 и группы пикроильменитов с низким гематитовым миналом $10 \%$ - Р14 и Р15. 


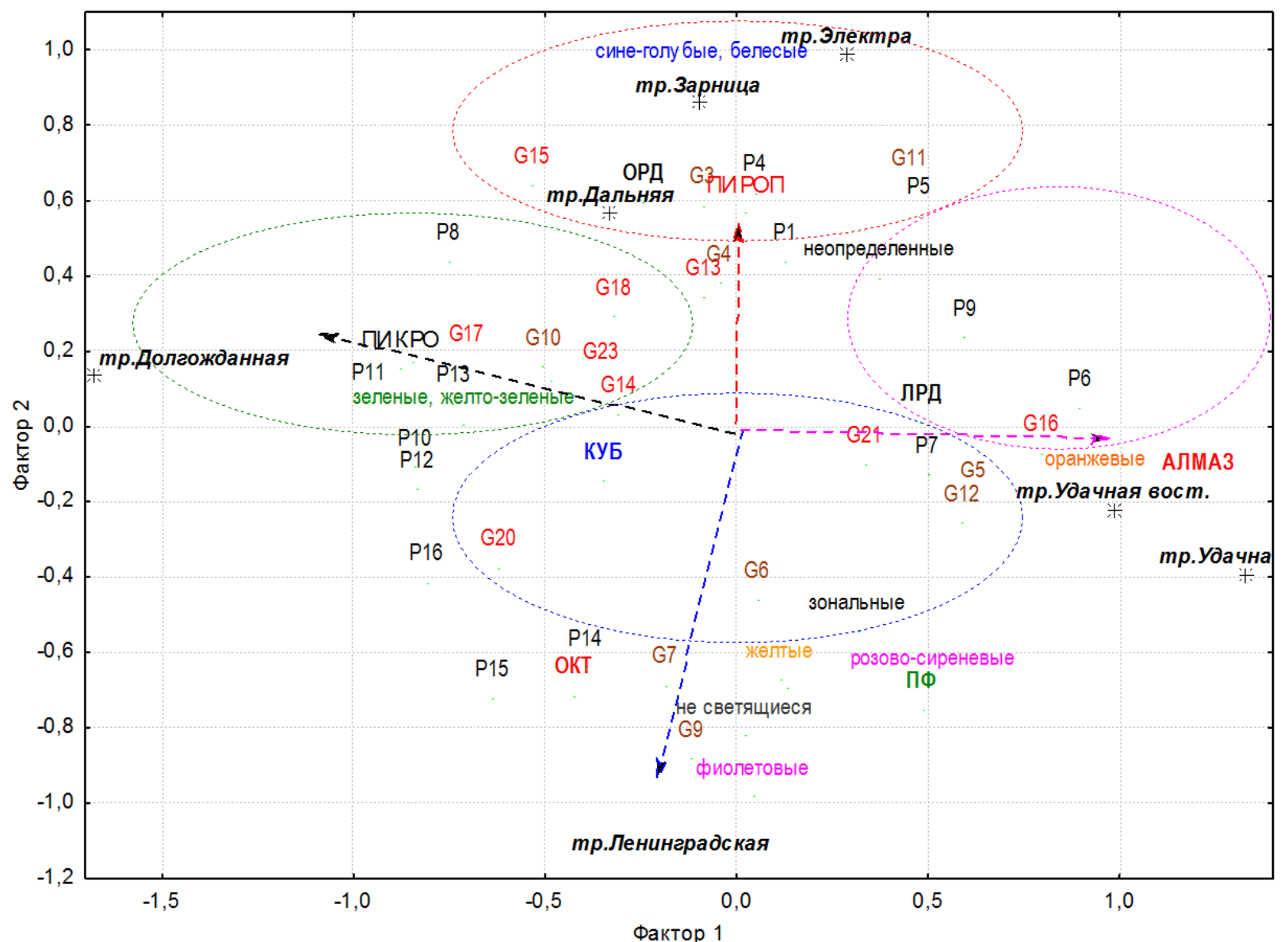

Puc. 8. Диаграмма главных факторов частот встречаемости кластерных групп ИМК, продуктивности тел (АЛМАЗ), цветов фотолюминесценции и кристалломорфологических форм алмазов кимберлитовых трубок Далдынского кимберлитового поля.

\section{Алакит-Мархинское кимберлитовое поле}

Для наиболее алмазоносной кимберлитовой тр. Айхал, по сравнению с другими кимберлитовыми трубками этого поля, характерно преобладание в выборках зёрен групп составов пикроильменитов с пониженными значениями гейкелитового минала (Р3P6). Это отличает ее от остальных кимберлитовых тел этого кимберлитового поля по составу пикроильменитов (рис. 9-11). Наличие зерен пикроильменитов выше перечисленных кластерных групп составов в тр. Айхал несут основную нагрузку в высокой значимой корреляции их частот встречаемости с алмазоносностью источников этого поля (более $+0,9$ ).

В трубке Айхал составы пиропов кластерной

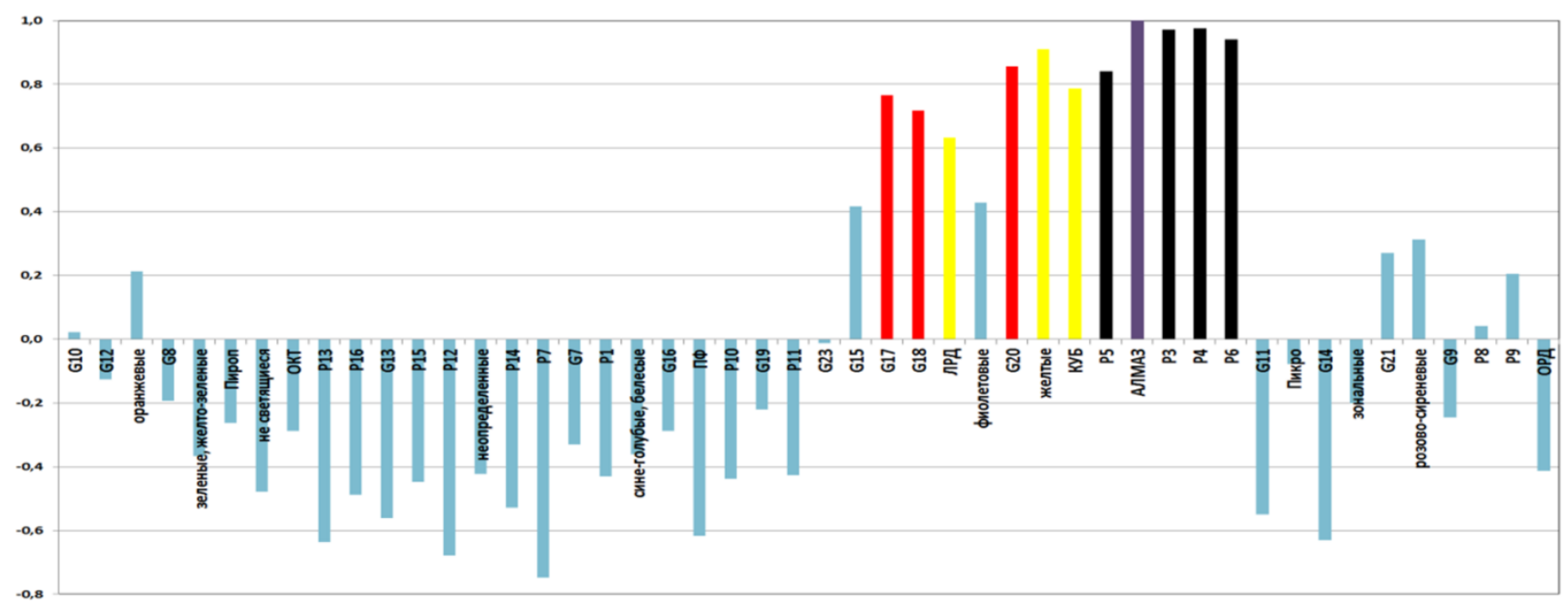

Pис. 9. Гистограммы парных групповых коэффициентов корреляции частот встречаемости кластерных групп ИМК, продуктивности тел (АЛМАЗ), цветов фотолюминесценции алмазов и их кристалломорфологических форм сгруппированные групповым кластерным анализом для Алакит-Мархинского кимберлитового поля. 


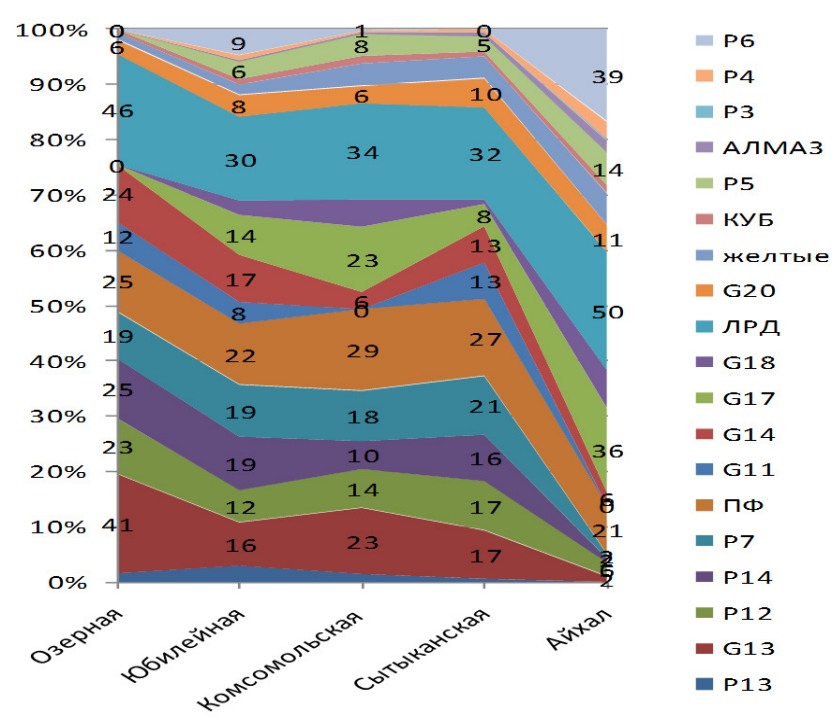

Puc. 10. Характер изменения значимых частот встречаемости кластерных групп ИМК (цифры - относительные от выборки проценты), продуктивности тел (АЛМАЗ), цветов фотолюминесценции алмазов и их кристалломорфологических форм от слабо алмазоносных к алмазоносным кимберлитам для Алакит-Мархинского кимберлитового поля.

группы G17 составляют более 35 \%. Эта группа определила основной значимый признак, который прямо и значимо взаимосвязан с продуктивностью этого ким- берлитового тела на алмазы. Точки составов зёрен этой группы все приходятся на центральную область ультраосновного тренда. За этим признаком идет группа составов пиропов G18 из низко хромистых алмазоносных дунит-гарцбургитовых парагенезисов. Зерен пиропов с такими составами в выборке отмечено более $16 \%$. что и является основной характеристикой по составам пиропов этой трубки, так как вместе они составляют более 50 \% от выборки зерен. Из основных кристалломорфологических форм повышено содержание кубов и кристаллов с желтой фотолюминесценцией. Преобладают не значительно, также в пробах тела тр. Айхал зерна пиропов группы G20 и кристаллы типа ЛРД.

В кимберлитах тр. Комсомольская отличительной группой составов пиропов является кластерная группа G19 - средне хромистых алмазоносных ультраосновных парагенезисов, которая является характеристической для данного типа кимберлита. С встречаемостью пиропов группы G19 коррелирует в этом теле частоты встречаемости содержаний алмазов октаэдрического габитуса. Также характерно для этого кимберлита преобладание зерен из двух резко различных по окиси хрома и алюминия групп пикроильмкенитов Р10 средне гейкелитовой с высоким хромом, и Р11 - с высоким корундовым миналом.

Для кимберлитовых тел тр. Юбилейная и тр. Сыты

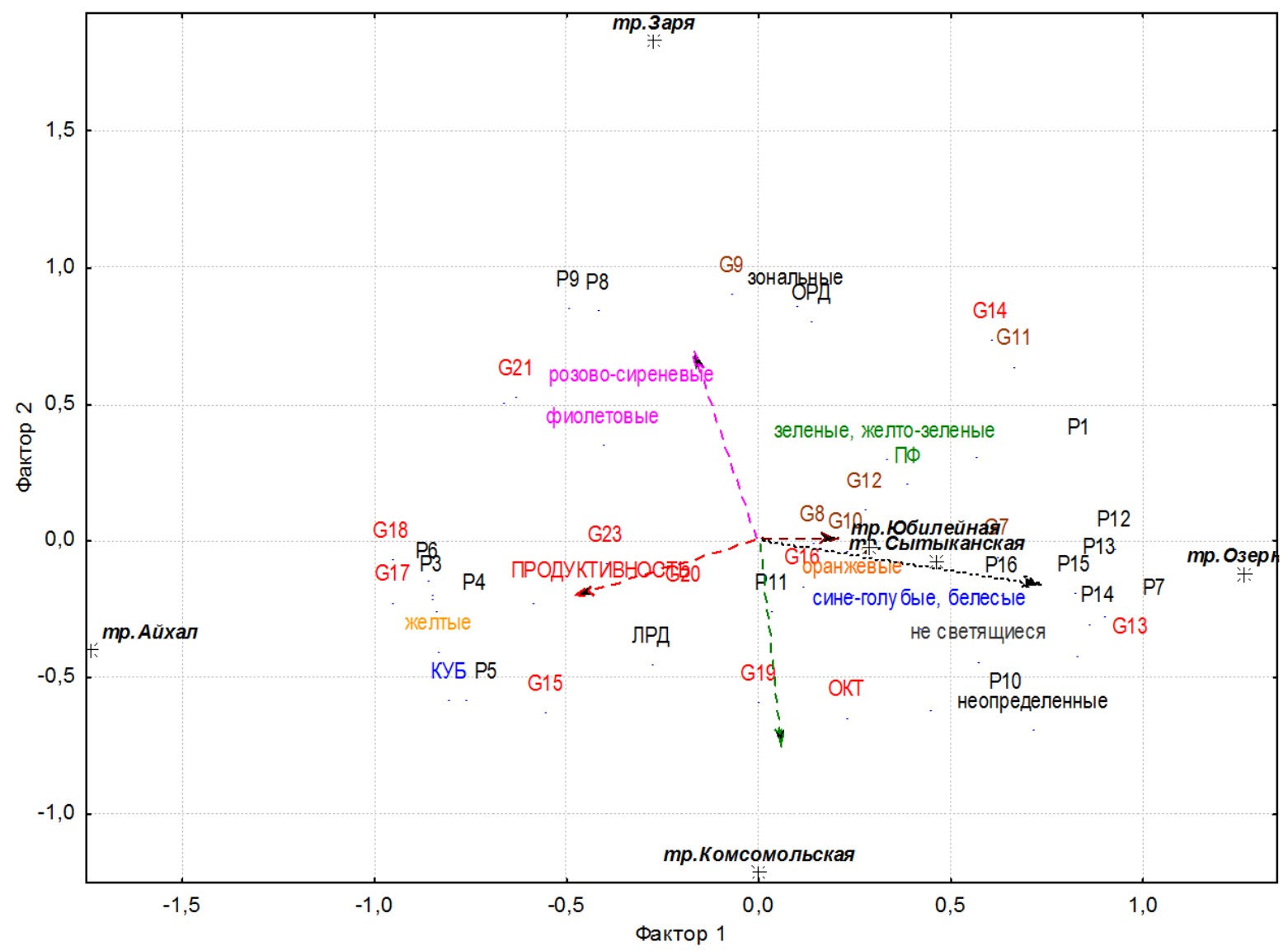

Puc. 11. Диаграмма главных факторов частот встречаемости кластерных групп ИМК, продуктивности тел (АЛМАЗ), цветов фотолюминесценции и кристалломорфологических форм алмазов кимберлитовых трубок Алакит-Мархинского кимберлитового поля. 
канская в целом отмечается повышенная продуктивность МСА с преобладанием пиропов над пикроильменитами. Отмечено повышенные содержания кристаллов алмазов в виде ПФ форм с оранжевой и зелено-желтой фотолюминесценцией и повышенные содержания пиропов эклогитовых парагенезисов групп G8, G10 и G12, частоты встречаемости которых не имеют значимых связей с частотами встречаемости кластерных групп пикроильменитов.

Для тр. Озёрной характерно повышенное содержание пикроильменитов групп составов с высоким гейкелитовым миналом (Р12-Р16), которые значимо связаны с группой пиропов эклогитовых парагенезисов G7 (более $+0,7)$ и группой ультраосновных парагенезисов G13 из гранатовых лерцолитов.

В кимберлитах тр. Заря при близких частотах встречаемости ОКТ, ПФ, ЛРД и ОРД отмечена повышенная продуктивность пикроильменитов до 15 кг на тонну породы, преобладание пиропов группы G9 и пикроильменитов групп Р8 и Р9. С весьма низкой (4 $\%$ частотой встречаемости алмазов с розовой, сиреневой и фиолетовой фотолюминесценцией коррелирует повышенное содержание высокохромистых пиропов группы G21 из алмазоносных парагенезисов.

\section{Выводы}

Частоты встречаемости определенных кластерных групп ИМК и их продуктивность находится в прямой и обратно высокой значимой корреляционной связи с определенными кристалломорфологическими и физическими свойствами алмазов. Комбинация значимо коррелирующих характеристик индивидуальна для определённого кимберлитового поля, что характеризует его как территориальную единицу, как кимберлитовое поле. Эти связи можно демонстрировать как на элементарных графиках зависимости, так и в виде корреляционных матриц. Такой расширенный статистический анализ дополняет паспортизацию кимберлитовых полей полнотой вещественных признаков, увеличивает вероятность соотнесения случайно найденных зёрен минералов из не представительных выборок проб к определенному типу кимберлитового источника. Наиболее значимым для этого являются составы пикроильменитов и кристалломорфологиче- ские формы алмазов, менее значимы цвета фотолюминесценции и составы пиропов. На физические свойства решетки кристаллов алмазов оказывает важное действие и геохимическая обстановка, существовавшая на всем протяжении его роста. На наш взгляд, присутствие минералов титана и железа, в процессе роста кристалла алмаза склоны приводить к смещению форм кристаллов в сторону ОРД и реже ЛРД форм в сочетании с повышенным содержанием кристаллов с зеленой и желто-зеленой фотолюминесценцией. Возможно, этот процесс протекает в особых РТ условиях, отличных от окружения с эклогитами, где РТ условия имеют более окисленные условия [4-5] и для алмазов более характерна розовая фотолюминесценция и октаэдрические кристаллы. Из результатов анализа вытекает прикладное значение полученных оценок, заключающееся в использовании в качестве поискового критерия кимберлитовых месторождений алмазов факта обнаружения определенных групп составов ИМК, для которых установлены значимые корреляционные связи с алмазоносностью.

\section{ЛИТЕРАТУРА}

1. Соболев, Н. В. О минералогических критериях алмазоносности кимберлитов / Н. В. Соболев // Геология и геофизика. - 1971. - № 3. - С. 70-80.

2. Иванов, A. C. Методика статистической обработки составов типоморфных минералов кимберлитовых трубок при поисках алмазов в Якутии / А. С. Иванов // Прикладная геохимия. Вып. 5, Компьютерные технологии. ; М. : ИМГРЭ. 2004. - C. $45-56$.

3. Иванов, А. С. О зависимости между частотами встречаемости кластерных групп составов МСА (пироп, пикроильменит), габитусных форм, цвета фотолюминесценции алмазов, продуктивности кимберлитов на МСА и алмазы / А. С. Иванов, Б. С. Помазанский // Труды ХІІІ Всероссийской (с международным участием) Ферсмановской научной сессии, посвящённой 50-летию Дня геолога (Апатиты, 4-5 апреля 2016 г.). - Апатиты, 2016. - С.169-181.

4. Квасница, В. Н. О парагенетической связи алмаз - гранат / В. Н. Квасница, С. С. Мацюк, В. И. Вуйко // Минер. журн. - 1984. - № 5. - С. 23-34.

5. Кристаллизация алмаза и графита в $\mathrm{COH}-$ флюиде при Р-Т параметрах природного алмазообразования / Ю. Н. Пальянов [и др.] // Докл. АН. - 2000. - Т. 375. - № 3. - С $384-388$.
Научно-исследовательское геологическое предприятие (НИГП) АК «АЛРОСА» (ПАО), РС (Я), г. Мирный

Иванов Александр Сергеевич, кандидат геологоминералогических наук, ведущий научный сотрудник лаборатории петрологии кимберлитов (ЛПК)

E-mail:IvanovAS@alrosa.ru

Тел.: +79142524307

Помазанский Богдан Степанович, заведующий лабораторией петрологии кимберлитов (ЛПК) E-mail:PomazanskiyBS@alrosa.ru

Тел.: +79142571428
Research Geological Enterprise (RGE) ALROSA, (PAO, Mirny, RF (Ya))

Ivanov A. S., candidate of geological and mineralogical sciences, the leading researcher of the laboratory of kimberlite petrology (LPK)

E-mail: IvanovAS@alrosa.ru

Tel.: +79142524307

Pomazansky B. S., the head of the laboratory of kimberlite petrology (LPK)

E-mail:PomazanskiyBS@alrosa.ru

Tel.: +79142571428 